\title{
IS MODULAR CONTROL RELATED TO FUNCTIONAL OUTCOMES IN INDIVIDUALS WITH KNEE OSTEOARTHRITIS AND FOLLOWING TOTAL KNEE ARTHROPLASTY?
}

\author{
Rebekah R. Koehn', Sarah A. Roelker ${ }^{2}$, Xueliang Pan ${ }^{3}$, Laura C. Schmitt ${ }^{4-6}$, Ajit M.W. \\ Chaudhari $^{1,4-8}$, Robert A. Siston ${ }^{1,4,5,7,8}$
}

${ }^{1}$ Department of Mechanical and Aerospace Engineering, The Ohio State University, Columbus, $\mathrm{OH}, \mathrm{USA}$

${ }^{2}$ Department of Kinesiology, University of Massachusetts Amherst, Amherst, MA, USA ${ }^{3}$ Center for Biostatistics and Bioinformatics, The Ohio State University, Columbus, OH, USA

${ }^{4}$ School of Health and Rehabilitation Sciences, The Ohio State University, Columbus, OH, USA

${ }^{5}$ Sports Medicine Research Institute, The Ohio State University Wexner Medical Center, Columbus, $\mathrm{OH}$, USA

${ }^{6}$ Division of Physical Therapy, School of Health and Rehabilitation Sciences, The Ohio State University, Columbus, OH, USA

${ }^{7}$ Department of Biomedical Engineering, The Ohio State University, Columbus, OH, USA ${ }^{8}$ Department of Orthopaedics, The Ohio State University, Columbus, OH, USA

Author Contributions:

RK: Conceptualization, Data Curation, Formal Analysis, Investigation, Methodology, Software, Visualization, Writing - Original Draft Preparation

SR: Conceptualization, Data Curation, Formal Analysis, Methodology, Software, Writing Review \& Editing

XP: Conceptualization, Formal Analysis, Funding Acquisition, Software, Writing - Review \& Editing

LS: Conceptualization, Funding Acquisition, Methodology, Writing - Review \& Editing

AC: Conceptualization, Funding Acquisition, Methodology, Resources, Writing - Review \&

Editing

RS: Conceptualization, Formal Analysis, Funding Acquisition, Investigation, Methodology, Project Administration, Resources, Supervision, Writing - Review \& Editing

Word count: 6704

Key Words: total knee arthroplasty, motor control, gait, muscle synergy, non-negative matrix factorization, electromyography 
medRxiv preprint doi: https://doi.org/10.1101/2021.11.04.21265894; this version posted December 17, 2021. The copyright holder for this preprint (which was not certified by peer review) is the author/funder, who has granted medRxiv a license to display the preprint in perpetuity.

All rights reserved. No reuse allowed without permission.

47

48

49

50

51

52

53

54
*Address Correspondence to:

Robert A. Siston

Department of Mechanical and Aerospace Engineering

Scott Laboratory

$201 \mathrm{~W} 19^{\text {th }}$ Ave

Columbus, OH 43210 USA

Phone: 614-247-2721

Email: siston.1@osu.edu 
medRxiv preprint doi: https://doi.org/10.1101/2021.11.04.21265894; this version posted December 17, 2021. The copyright holder for this

ABSTRACT

BACKGROUND: Individuals who undergo total knee arthroplasty (TKA) for treatment

57 of knee osteoarthritis often experience suboptimal outcomes. Investigation of neuromuscular

58 control strategies in these individuals may reveal factors that contribute to these functional deficits.

59 The purpose of this pilot study was to determine the relationship between patient function and

60 modular control during gait before and after TKA. METHODS: Electromyography data from 36

61 participants (38 knees) were collected from 8 lower extremity muscles on the TKA-involved limb

62 during $\geq 5$ over-ground walking trials before $(n=30), 6$-months after $(n=26)$, and 24-months after

63 (n=13) surgery. Muscle modules were estimated using non-negative matrix factorization. The

64 number of modules was determined from 500 resampled trials. RESULTS: A higher number of

65 modules was related to better performance-based and patient-reported function before and 6-

66 months after surgery. Participants with organization similar to healthy, age-matched controls

67 trended toward better function 24-months after surgery, though these results were not statistically

68 significant. We also observed plasticity in the participants' modular control strategies, with $100 \%$

69 of participants who were present before and 24-months after surgery (10/10) demonstrating

70 changes in the number of modules and/or organization of at least 1 module. CONCLUSIONS:

71 This pilot work suggests that functional improvements following TKA may initially present as

72 increases in the number of modules recruited during gait. Once individuals can produce discrete

73 neuromuscular control patterns, further improvements may present as improved module

74 organization. NOTEWORTHY: This work is the first to characterize motor modules in TKA both

75 before and after surgery and to demonstrate changes in the number and organization of modules

76 over the time course of recovery, which may be related to changes in patient function. The

77 plasticity of modular control following TKA is a key finding which has not been previously 
medRxiv preprint doi: https://doi.org/10.1101/2021.11.04.21265894; this version posted December 17, 2021. The copyright holder for this preprint (which was not certified by peer review) is the author/funder, who has granted medRxiv a license to display the preprint in perpetuity. All rights reserved. No reuse allowed without permission.

78 documented and may be useful in predicting or improving surgical outcomes through novel 79 rehabilitation protocols. 
medRxiv preprint doi: https://doi.org/10.1101/2021.11.04.21265894; this version posted December 17, 2021. The copyright holder for this

\section{INTRODUCTION}

Total knee arthroplasty (TKA) is the definitive end-stage treatment for knee osteoarthritis

82 (KOA), with over 750,000 primary TKAs occurring in 2014 and over 1.25 million primary TKAs

83 expected in the U.S. annually by 2030 (1). While TKA improves function in most patients, more

84 than $20 \%$ of adults demonstrate functional deficits 2-years post-TKA (2). These functional deficits

85 include slower walking speeds (3), stiff-knee gait (4), and difficulty in stair descent (5) and sit-to-

86 stand transfer (6). Several studies have suggested that these deficits are influenced by a variety of

87 factors including implant design (7), surgical technique (8), ligament laxity and soft tissue balance

88 (9), quadriceps strength (10), strength of the non-operated limb (11), and preoperative conditions

89 (12). However, the primary factor or combination of factors which reliably predict patient

90 outcomes has yet to be determined.

91 Several studies have also examined neuromuscular control as a factor which may explain

92 the functional deficits seen in this population. One study found that TKA patients, both before and

93 1-month after surgery, demonstrated higher co-activation of the quadriceps and hamstrings during

94 stand-to-sit transfer and performed the five-times-sit-to-stand task more slowly than healthy adults

95 (13). Another study determined that TKA patients demonstrated quadriceps muscle activation

96 deficits after surgery, but these deficits were not associated with quadriceps strength 3-months

97 after TKA (14). Some work has also been done to investigate changes in patient function and

98 neural control in this population from the preoperative to postoperative condition. Hubley-Kozey

99 et al. (15) studied patient function and muscle activation patterns in patients before and 1-year

100 following TKA and found that while functional improvements were accompanied by shifts in

101 activation patterns toward the patterns of asymptomatic individuals, the patterns were still

102 statistically different from the asymptomatic individuals. While these studies provide valuable 
medRxiv preprint doi: https://doi.org/10.1101/2021.11.04.21265894; this version posted December 17, 2021. The copyright holder for this preprint (which was not certified by peer review) is the author/funder, who has granted medRxiv a license to display the preprint in perpetuity. All rights reserved. No reuse allowed without permission.

103 insight into the influence of activation patterns on function in KOA and TKA, it is still unknown 104 how these electromyography (EMG)-measured factors may change over the time course of 105 recovery after surgery. Further, it remains unclear if changes in co-activations and muscle 106 activation patterns are indicative of changes in the underlying neuromuscular control strategies.

107 Since individual EMG waveforms alone do not provide insight into the underlying mechanisms of 108 control, other tools are necessary in order to determine the influence of neuromuscular control on 109 patient function.

110 The theory of modular muscle control has gained popularity as a tool to explore 111 neuromuscular control (16). The theory describes a simplified neural control strategy in which a 112 group of muscles is activated synergistically by a common neural command, reducing the set of 113 activation profiles used to complete a motion (17). The number of these commands, or "motor 114 primitives" (18), and the organization of muscles within the modules, which are selected out of an 115 individual's library of possible commands in order to complete a task, represent varying 116 complexity of control patterns (19-21). A higher number of modules used to complete a task, such

117 as walking, may indicate a more complex neuromuscular control strategy and greater flexibility in 118 control (21). Muscles that are organized into a specific module activate as a group according to 119 the module's timing profile, and recent literature has suggested that populations with neurologic 120 movement disorders, including Parkinson's disease, post-stroke hemiparesis, and incomplete 121 spinal cord injury, demonstrate altered module organization in comparison to healthy controls (22122 25). To our knowledge, there has been only one study examining modular control in the TKA 123 population. Ardestani et al. (21) found that 1-year following a cruciate retaining (CR) TKA, a low124 functioning group of participants demonstrated 2-3 motor modules while a high-functioning group 125 demonstrated 4-5 modules, which more closely resembled a healthy control group that 
medRxiv preprint doi: https://doi.org/10.1101/2021.11.04.21265894; this version posted December 17, 2021. The copyright holder for this preprint (which was not certified by peer review) is the author/funder, who has granted medRxiv a license to display the preprint in perpetuity. All rights reserved. No reuse allowed without permission.

126 demonstrated 5-6 modules. The results of that study suggest that the complexity of neural control

127 strategy may be an underlying mechanism that contributes to the large range of post-operative

128 functional outcomes observed in this population. However, the relationship between module

129 organization and function has yet to be characterized in the TKA population. Additionally, it has

130 been suggested that rehabilitation programs may influence the complexity and organization of

131 modular control in individuals with spinal cord injuries or neurological disorders $(22,26)$.

132 However, it is still unknown whether changes in modular control exist in individuals with

133 orthopaedic disorders and whether such changes may be related to the time course of functional

134 improvements following surgical interventions, like TKA.

Therefore, the purpose of this pilot study was to determine the relationship between patient

136 function and modular control during gait before and at two timepoints after surgery and to

137 investigate the plasticity of neuromuscular control in the KOA and TKA populations. We

138 hypothesized that better patient function before surgery, 6-months after surgery, and 24-months

139 after surgery would be associated with (I) a higher number of modules and (II) module

140 organization more similar to that of healthy controls. Additionally, we aimed to examine the

141 relationship between changes in function and changes in the number and organization of modules

142 over the time course of recovery from TKA.

144 MATERIALS \& METHODS

145 Data Collection

146 Prior to enrolling in the original longitudinal study (27), 36 individuals (38 knees) with

147 medial compartment KOA (19/19 R/L) provided written informed consent, in accordance with The

148 Ohio State University's Institutional Review Board. The cohort in the current study is a superset 
medRxiv preprint doi: https://doi.org/10.1101/2021.11.04.21265894; this version posted December 17, 2021. The copyright holder for this preprint (which was not certified by peer review) is the author/funder, who has granted medRxiv a license to display the preprint in perpetuity. All rights reserved. No reuse allowed without permission.

149 of that reported in Freisinger et al. (27), which examined gait biomechanics before surgery, and 150 Chaudhari et al. (28), which examined muscle strength before and after surgery. Three orthopaedic

151 surgeons (JFG, AHG, MDB; see acknowledgements) identified potential participants based on 152 consultation for a TKA at The Ohio State Wexner Medical Center. Participants were required to 153 have a body-mass index (BMI) less than 45, the ability to walk 20 meters without an assistive 154 device, and no history of previous TKA or osteotomy. Recruitment began in April 2012 and 155 continued on a rolling basis, and data was collected from May 2012 to May 2017. All participants 156 were scheduled to undergo a primary posterior-stabilizing (PS) TKA (Zimmer NexGen LPS Flex 157 Knee) prior to study recruitment. By consensus, two fellowship-trained musculoskeletal 158 radiologists (JP, AR; see acknowledgements) determined the Kellgren-Lawrence classification 159 (KL-grade) of each participant's right and left knees (29). The participants were tested in the Clinical, Functional, and Performance Biomechanics

161 Laboratory at The Ohio State University approximately 1-month before, 6-months after, and 24162 months after undergoing surgery. Each participant performed a minimum of 5 over-ground 163 walking trials. Surface EMG data were collected at $1500 \mathrm{~Hz}$ (Telemyo DTS System, Noraxon, 164 Scottsdale, AZ) from $16 \mathrm{Ag} / \mathrm{AgCl}$ dual-electrodes (Peripheral Nerve Stimulation Dual Element 165 Electrodes, rectangular, 1.625 in $\times 3.25$ in, 0.42 in sensor diameter, 1.625 in inter-electrode 166 distance, Vermed, Buffalo, NY) affixed over the bellies of 8 lower extremity muscles, bilaterally: 167 rectus femoris, vastus lateralis, vastus medialis, biceps femoris, medial hamstrings, lateral 168 gastrocnemius, medial gastrocnemius, and soleus. Prior to affixing the electrodes, the skin over 169 each muscle was shaved to remove any hair and then cleansed and lightly abraded with alcohol 170 wipes. 
medRxiv preprint doi: https://doi.org/10.1101/2021.11.04.21265894; this version posted December 17, 2021. The copyright holder for this

In addition to gait trials, several performance-based and patient-report measures of function

172 were recorded. Each participant completed three clinical performance-based assessments: the

173 timed stair-climbing test (SCT) (30), the timed up-and-go test (TUG) (31), and the six-minute walk

174 test (6MW) (32). Each participant also provided self-reported functional data using four of the

175 Knee Injury and Osteoarthritis Outcome Score (KOOS) (33) survey subscales: pain, symptoms,

176 activities of daily living (ADL), and quality of life (QOL). For each question, the participants'

177 answers were scored on a scale from 0 to 4 , with a higher score indicating better self-reported

178 function. The scores were totaled within each subscale and normalized such that a maximum score

179 of 100 represented high function and a minimum score of 0 represented poor function.

Due to high BMI (e.g. $33.9 \pm 5.1 \mathrm{~kg} / \mathrm{m}^{2}$ before TKA), a common trait in individuals with

181 osteoarthritis, soft tissue motion artifact was present in the EMG data in many of the trials. Due to

182 this motion artifact, several participants were excluded from the study. Additionally, all 36

183 participants did not appear at all three data collection sessions. We were able to include data for

18430 participants before surgery, 26 participants at 6-months post-TKA, and 13 participants at 24-

185 months post-TKA (Table 1) in this pilot study.

186

\section{Identification of Muscle Modules}

We processed the EMG data for the TKA-involved limb from each gait trial to prepare for

module extraction. The EMG data were demeaned and bandpass filtered to frequencies between

$19050 \mathrm{~Hz}$ and $300 \mathrm{~Hz}$ (Butterworth, $6^{\text {th }}$ order) due to higher levels of motion artifact associated with

191 high BMI values in this population, as recommended by Kieliba et al. (34) and Santuz et al. (35).

192 The EMG data were then full-wave rectified and smoothed using a $6 \mathrm{~Hz}$ lowpass filter

193 (Butterworth, $6^{\text {th }}$ order). Trials with excessive motion artifact were excluded. We extracted the 
medRxiv preprint doi: https://doi.org/10.1101/2021.11.04.21265894; this version posted December 17, 2021. The copyright holder for this preprint (which was not certified by peer review) is the author/funder, who has granted medRxiv a license to display the preprint in perpetuity. All rights reserved. No reuse allowed without permission.

194

195

196

197

198

199

200

201

202

203

204

205

206

207

208

209

210

211

212

213

214

$$
t V A F=\left(1-\frac{\sum_{m=1}^{8}\left(E M G_{o, m}-E M G_{r, m}\right)^{2}}{\sum_{m=1}^{8} E M G_{o, m}^{2}}\right) \times 100 \% \quad \text { Equation } 2
$$

maximum number of available gait cycles from each participant, and those with fewer than 5 available gait cycles were excluded. Linear envelopes were formed by discretizing the data such that each trial contained 201 data points, accounting for every $0.5 \%$ of the gait cycle, concatenating all available gait cycles, and normalizing each muscle first to the maximum value across all gait cycles and then to unit variance (36).

Muscle modules were calculated using non-negative matrix factorization (NMF) (37). Given that neuron firing rates and strengths cannot be negative, NMF provides insight into an individual's neural control strategy that can be interpreted physiologically (16). First, the linear envelopes for each subject were organized into $m x t$ matrices representing the original EMG $\left(\mathrm{EMG}_{\mathrm{o}}\right.$ ), where $m$ is the number of muscles (i.e. $\left.m=8\right)$ and $t$ is the number of data points (i.e. $t=$ $201 \times$ the number of gait cycles available). The NMFs were performed using the Statistics and Machine Learning Toolbox in Matlab R2017a (The MathWorks Inc.; Natick, MA) which populated an $n \times t$ matrix (Pattern Matrix) and an $m \times n$ matrix (Weighting Matrix), where $n$ is the number of modules. The Pattern Matrix represents the temporal waveform of each module while the Weighting Matrix represents the weight of each muscle within each of the modules, such that the product of these matrices $\left(\mathrm{EMG}_{\mathrm{r}}\right)$ reconstructs $\mathrm{EMG}_{\mathrm{o}}$ (Fig. 1). The sum of the squared errors between $\mathrm{EMG}_{\mathrm{r}}$ and $\mathrm{EMG}_{\mathrm{o}}$ was quantified with the percent of variability accounted for (VAF). The VAF was calculated for each muscle (mVAF) of each solution using:

$$
m V A F=\left(1-\frac{\left(E M G_{o, m}-E M G_{r, m}\right)^{2}}{E M G_{o, m}^{2}}\right) \times 100 \% \quad \text { Equation } 1
$$

and the total VAF (tVAF) for each solution was calculated using: 
medRxiv preprint doi: https://doi.org/10.1101/2021.11.04.21265894; this version posted December 17, 2021. The copyright holder for this preprint (which was not certified by peer review) is the author/funder, who has granted medRxiv a license to display the preprint in perpetuity.

All rights reserved. No reuse allowed without permission.

Muscle Weights

Weighting Matrix
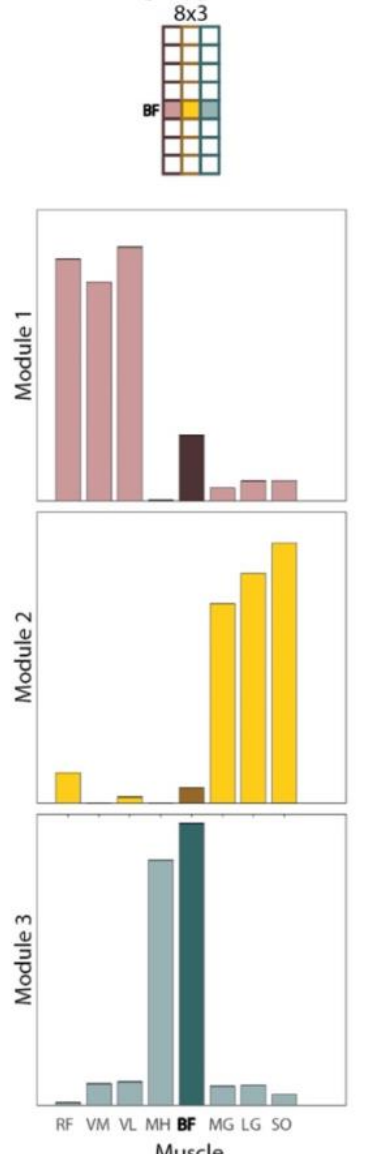

Muscle
Activation Timing

Profiles
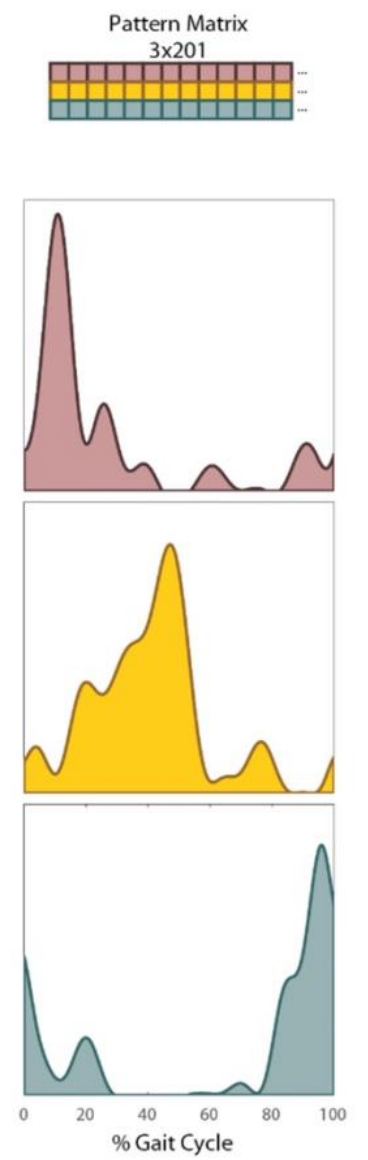

Reconstructed

Activations
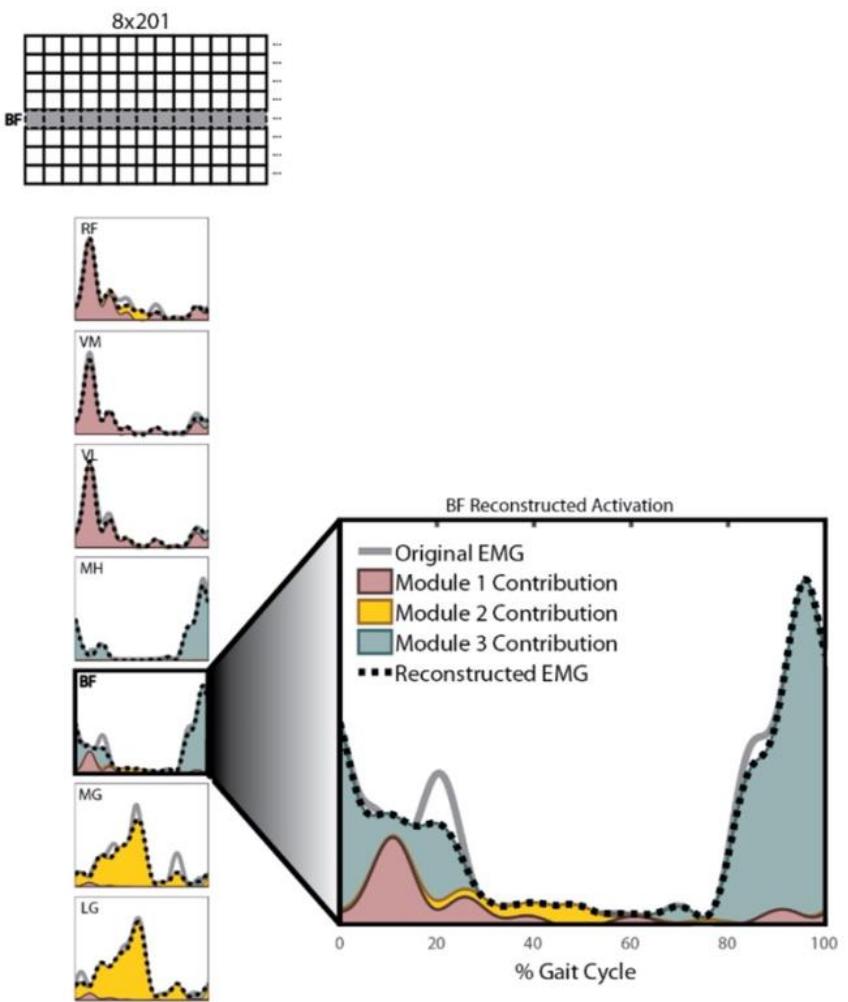
modules was increased from 1 to $m$ (i.e., $m=8$; the number of muscles recorded) in separate NMFs Fig. 1: Example of EMG Reconstruction using Non-Negative Matrix Factorization. Muscle modules were calculated using non-negative matrix factorization (NMF) in which an $m \times n$ Weighting Matrix is multiplied by an $n x t$ Pattern Matrix to reconstruct the EMG patterns in an $m x t$ matrix, where $m$ is the number of muscles ( 8 in this study), $n$ is the number of modules ( 3 in this example), and $t$ is the number of data points in the trial (201 in this study). The Pattern Matrix represents the timing profile of each module. The Weighting Matrix represents how strongly each muscle is represented in the module. This process is iterated, increasing $n$ from 1 to $m$ until the error between the reconstructed EMG (black dotted line) and the original EMG (solid gray line) is reduced to some acceptable level determined by the variability accounted for (VAF) criteria.

In order to find the number of modules required to reconstruct $\mathrm{EMG}_{\mathrm{o}}$, the number of 
medRxiv preprint doi: https://doi.org/10.1101/2021.11.04.21265894; this version posted December 17, 2021. The copyright holder for this preprint (which was not certified by peer review) is the author/funder, who has granted medRxiv a license to display the preprint in perpetuity. All rights reserved. No reuse allowed without permission.

235 minimum lower bound of the $95 \%$ CI of all mVAFs was greater than $75 \%$, or (b) the minimum 236 lower bound of the $95 \% \mathrm{CI}$ for all mVAFs was greater than $75 \%$ and the addition of another 237 module did not raise the lower bound of the $95 \% \mathrm{CI}$ for that mVAF by more than $5 \%$ of its value 238 in the previous NMF (24). The 95\% CIs of the VAFs were found using a bootstrapping technique 239 adopted from Allen et al. (22), wherein $\mathrm{EMG}_{\mathrm{o}}$ was resampled 500 times with replacement. The $24095 \%$ CI was assembled from the VAFs of all 500 bootstrapped samples. Once the appropriate 241 number of modules was determined, we ran a final NMF on the original EMG using a 242 multiplicative update algorithm with 50 replicates. To allow for comparison of modules between 243 participants and timepoints, the Weighting Matrix was normalized to the maximum muscle weight 244 within that module. Additionally, we evaluated tVAF for all possible module solutions (i.e. 1 245 module, 2 modules, ..., 8 modules) as a measure of the complexity of the control strategy. A higher 246 tVAF value for any given module solution represents a better fit between $\mathrm{EMG}_{\mathrm{r}}$ and $\mathrm{EMG}_{\mathrm{o}}$. 247 Therefore, a low tVAF value indicates that the solution is not capable of fully capturing the 248 complexity of the actual control strategy.

To characterize modular organization, we adapted definitions of $\mathrm{W}_{\text {musc }}$ and $\mathrm{W}_{\text {sum }}$ from 250 Hayes et al. (25). The number of significantly active muscles in each module was defined as $\mathrm{W}_{\text {musc, }}$ 251 and the sum of the weights of the significantly active muscles in each module was defined as $\mathrm{W}_{\text {sum. }}$.

252 In Hayes et al. (25) a muscle was considered significantly active if the 95\% CI of weights for the 253500 bootstrapped gait cycles did not contain 0 . However, participants in the current study often 254 had confidence intervals with a lower bound greater than zero but a very small upper bound. Under 255 the original definition from Hayes et al. (25), all modules for all participants in the TKA cohort 256 had a $\mathrm{W}_{\text {musc }}$ of 7 or 8 , meaning all muscles were significantly active in all modules. To uncover 257 more subtle differences in $\mathrm{W}_{\text {musc }}$ and $\mathrm{W}_{\text {sum }}$ between participants in our cohort, we adapted the 
medRxiv preprint doi: https://doi.org/10.1101/2021.11.04.21265894; this version posted December 17, 2021. The copyright holder for this preprint (which was not certified by peer review) is the author/funder, who has granted medRxiv a license to display the preprint in perpetuity. All rights reserved. No reuse allowed without permission.

258 definition of "significantly active," such that a muscle was considered significantly active if the

$25995 \%$ CI of weights did not contain 0 and the upper bound was greater than 0.25 . Modules from each of the 500 samples were sorted using a k-means algorithm to ensure like-modules were grouped prior to determining the $95 \%$ CIs for the weights (38).

262

\section{Healthy Control Group}

Motor modules from 10 older adults with no known lower extremity osteoarthritis, a subset

265 of the cohort used in Roelker et al. (38), were used as healthy, age-matched controls to compare

266 to the KOA and TKA data. The processes for data collection and identification of muscle modules

267 are consistent with this study, with the exception of the bandpass filter used to process the EMG

268 data. Roelker et al. (38) used a 30-300 Hz bandpass filter while we used a 50-300 Hz bandpass

269 filter in the current study due to the previously mentioned high BMI and resulting motion artifact

270 observed in the TKA cohort. We determined $\mathrm{W}_{\text {musc }}$ and $\mathrm{W}_{\text {sum }}$ for each module for each healthy

271 participant based on our new definition for "significantly active" muscles.

272

273 Comparison of Module Organization

274 To determine similarities in module organization between populations, we compared the

275 module weightings of the study participants to those of the healthy controls. The muscle weights

276 of each module for each participant at each timepoint were compared to the averaged weights of

277 healthy age-matched controls with the same number of modules using Pearson correlations. A

278 critical correlation coefficient of $\rho \geq 0.834$ was selected based on the number of muscles (8) and

279 a $p$-value of $0.01(22,23,25)$. A module was considered to have proper organization if its weights

280 were correlated with the healthy group and its $\mathrm{W}_{\text {musc }}$ and $\mathrm{W}_{\text {sum }}$ values were within the 95\% CIs of 
medRxiv preprint doi: https://doi.org/10.1101/2021.11.04.21265894; this version posted December 17, 2021. The copyright holder for this preprint (which was not certified by peer review) is the author/funder, who has granted medRxiv a license to display the preprint in perpetuity. All rights reserved. No reuse allowed without permission.

281 the healthy group. Participants were considered to have proper organization if all of their modules

282 were organized like healthy controls and poor organization if at least one module did not have

283 healthy organization.

284

285

Minimum Detectable Changes in Functional Performance

Differences in performance-based and self-reported measures were evaluated based on

287 minimum detectable changes (MDCs), defined by previously reported 90\% CIs from

288 representative populations. Improvements were indicated by decreases in the time to complete

289 SCT ( $\geq 1.9$ seconds; (39)) and TUG ( $\geq 2.49$ seconds; (32)), increases in the distance walked during

$2906 \mathrm{MW}(\geq 61.34$ meters; (32)), and increases in all KOOS subscales ( $\geq 10$ points; (33)).

291

292

293 Statistics

To address our hypotheses, we investigated the relationship between functional

295 performance measures and modules in terms of their number (Hypothesis I) and organization

296 (Hypothesis II). At each time point, the functional measures were summarized by the number or 297 organization of modules. Generalized linear mixed models (GLMM) for repeated measures were 298 used to estimate the effects of number of modules and module organization (proper or poor) on all 299 functional measures at each time point. Time point, module number/organization, and their 300 interaction were included as fixed effects and participants were included as random effects in the

301 GLMMs. GLMMs allowed us to include all participants, even with missing data, assuming data 302 was missing at random in the analysis. 
medRxiv preprint doi: https://doi.org/10.1101/2021.11.04.21265894; this version posted December 17, 2021. The copyright holder for this preprint (which was not certified by peer review) is the author/funder, who has granted medRxiv a license to display the preprint in perpetuity. All rights reserved. No reuse allowed without permission.

We examined differences in demographics, function, and modules between time points for 304 the TKA cohort and also examined differences in demographics and number of modules between 305 the TKA and healthy cohorts. Separate GLMMs were used to estimate the changes over time in 306 demographics data (height, mass, BMI, self-selected walking speed, stride length normalized to 307 leg length), performance-based function (SCT, TUG, 6MW), KOOS-subscale scores (Pain, 308 Symptoms, ADL, QOL), number of modules, and module organization (proper or poor). Separate 309 unpaired, two-tailed t-tests (all data was normally distributed; Anderson-Darling test for normality, 310 all $p \geq 0.052$ ) compared demographics data between the TKA group at 24-months after surgery 311 and the healthy control group. A Chi-square test compared number of modules between the healthy 312 control group and the group tested at 24-months post-TKA. As an additional examination of 313 module complexity, we used GLMMs to estimate differences in tVAF for all possible module 314 solutions (i.e. 1 to 8 modules) between time points.

All GLMMs were performed using Statistical Analysis Software (SAS Institute Inc.; Cary, 316 NC). Main effects were estimated from the fixed effects parameters or their corresponding contract 317 of the parameters from the GLMM, and, if significant, pairwise differences were assessed based 318 on the least squares means difference. All other statistical analysis was performed using Minitab 319 (Minitab, LLC; State College, PA). A significance level of $\alpha<0.05$ was established a priori for all 320 tests.

\section{RESULTS}

323 Population Demographics and Modules

The TKA group had statistically significant changes over time in self-selected walking 325 speed $(p=0.001)$ and BMI $(p=0.043$; Table 1). Self-selected walking speed increased over time 
medRxiv preprint doi: https://doi.org/10.1101/2021.11.04.21265894; this version posted December 17, 2021. The copyright holder for this preprint (which was not certified by peer review) is the author/funder, who has granted medRxiv a license to display the preprint in perpetuity.

All rights reserved. No reuse allowed without permission.

and was slower before surgery than at 6- (pairwise $p=0.007$ ) and 24-months (pairwise $p<0.001$ )

before (pairwise $p=0.018$ ) or 6-months (pairwise $p=0.049$ ) after surgery. Between the TKA

Table 1: Demographics, Modules, and Function.

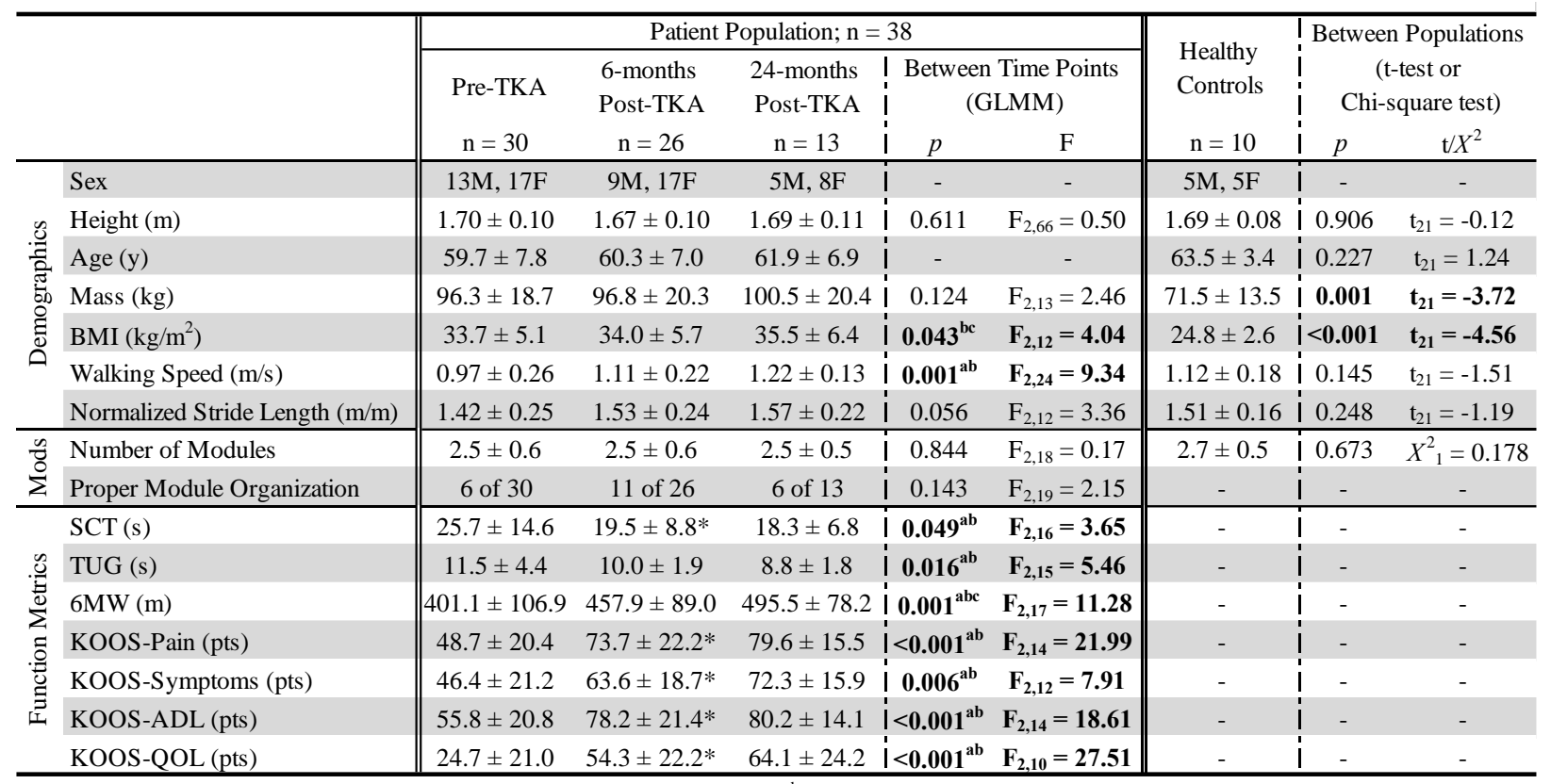

Symbols indicate differences between: ${ }^{\mathrm{a}}$ Pre-TKA and 6-months Post-TKA, ${ }^{\mathrm{b}}$ Pre-TKA and 24-months Post-TKA, ${ }^{\mathrm{c}} 6-$ and $24-$ months Post-TKA

Average demographics, module metrics, and function metrics grouped by time point and population ( \pm 1 standard deviation). The healthy control group was compared to the group of participants tested at 24-months post-TKA. 
medRxiv preprint doi: https://doi.org/10.1101/2021.11.04.21265894; this version posted December 17, 2021. The copyright holder for this preprint (which was not certified by peer review) is the author/funder, who has granted medRxiv a license to display the preprint in perpetuity. All rights reserved. No reuse allowed without permission.

344 dominated by the plantarflexors, quadriceps, and hamstrings, separately. Before surgery, 16 345 individuals with TKA demonstrated 2 modules and 14 demonstrated 3 modules, and 6 of the 30 346 (20.0\%) participants had proper organization. By 6-months after surgery, 12 demonstrated 2 347 modules and 14 demonstrated 3 modules, and 11 of the $26(42.3 \%)$ participants had proper module 348 organization. By 24-months after surgery, 5 participants demonstrated 2 modules and 8 349 demonstrated 3 modules, and 6 of the $13(46.2 \%)$ participants had proper organization. There was 350 no difference in number of modules $(p=0.844)$ or module organization $(p=0.143)$ between time 351 points (Table 1).

There were differences in mean tVAF values between time points for solutions with 1, 2,

3536 , and 7 modules (Fig. 2). For the 1-module solution, the group tested before surgery (79.8 $\pm 6.3 \%)$

354 had a statistically higher mean tVAF value than those at 6-months $(75.7 \pm 6.3 \%$; pairwise $p=$ $3550.001)$ and 24-months $(72.9 \pm 8.2 \%$; pairwise $p=0.003)$ after surgery. For the 2-module solution, 356 the group tested before surgery $(91.2 \pm 2.6 \%)$ had a statistically higher mean tVAF than those at 357 24-months after surgery $(89.3 \pm 2.7 \%$; pairwise $p=0.033)$. For the 6-module solution, the group 358 tested before surgery $(99.3 \pm 0.3 \%)$ had a statistically higher mean tVAF than those at 24-months 359 after surgery $(99.1 \pm 0.3 \%$; pairwise $p=0.016)$. For the 7 -module solution, the group tested before 360 surgery $(99.7 \pm 0.1 \%)$ had a statistically higher mean tVAF than those at 6-months $(99.7 \pm 0.1 \%$;

361 pairwise $p=0.040)$ and 24-months (99.6 $\pm 0.2 \%$; pairwise $p=0.004)$ after surgery. 
medRxiv preprint doi: https://doi.org/10.1101/2021.11.04.21265894; this version posted December 17, 2021. The copyright holder for this preprint (which was not certified by peer review) is the author/funder, who has granted medRxiv a license to display the preprint in perpetuity.

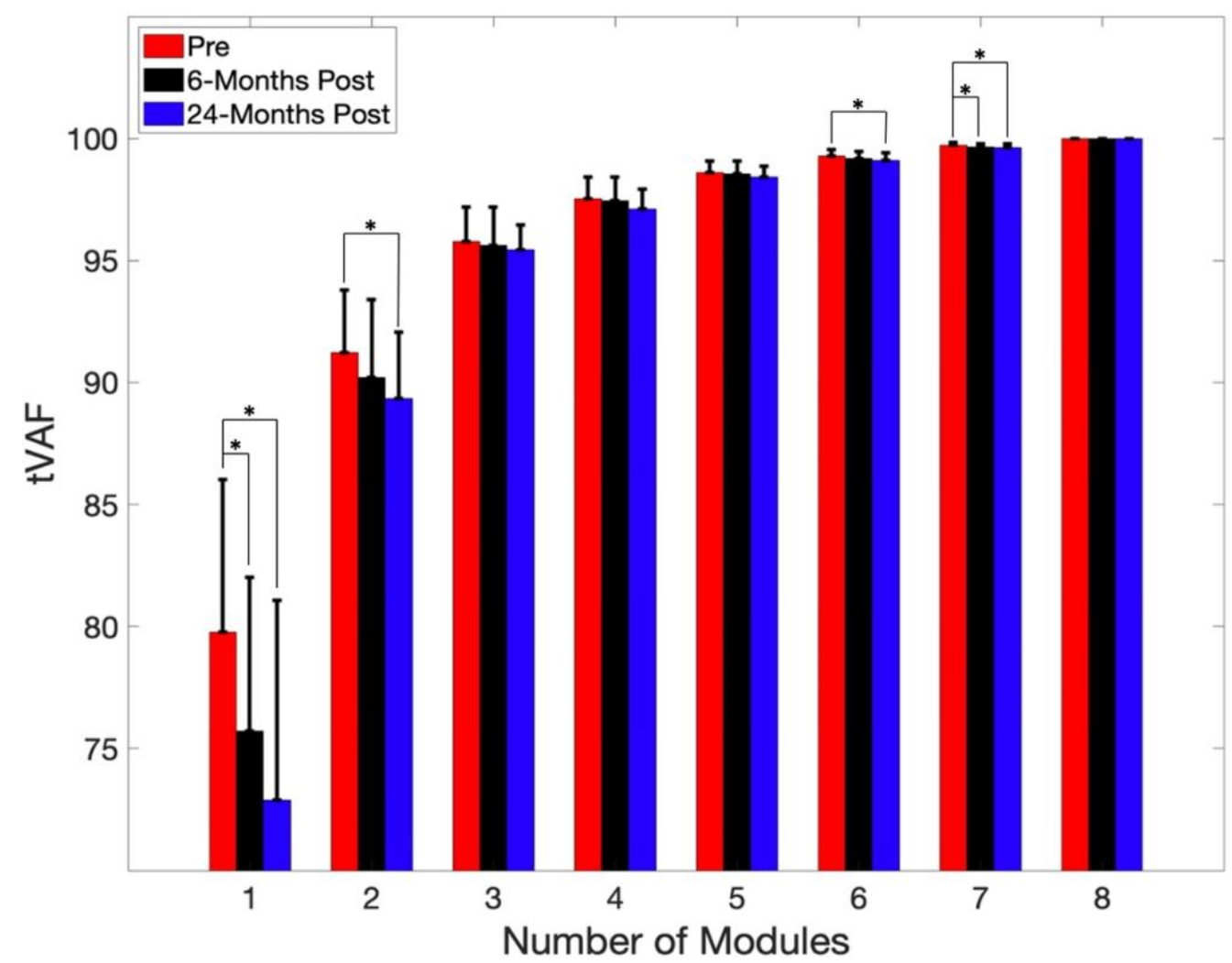

Fig. 2: tVAF for All Module Solutions. Estimated mean tVAF by time point for number of modules varying from 1 to 8 . Error bars represent +1 standard deviation. * indicates statistically

The worst averaged functional scores were observed before surgery and the best averaged

369 functional scores were observed 24-months after surgery (Table 1). All measures were statistically

370 different between timepoints (all $p \leq 0.049$ ). From before to 6-months after surgery, all measures

371 had statistically significant improvements (all pairwise $p \leq 0.031$ ), and these improvements were

372 also clinically meaningful for the SCT and all KOOS subscales. From before to 24-months after

373 surgery, all measures had statistically significant (all pairwise $p \leq 0.020$ ) and clinically meaningful

374 improvements. Average 6MW distance also had a statistically significantly improvement from 6-

375 to 24-months after surgery (pairwise $p=0.036$ ), but this improvement was not clinically

376 meaningful. 
medRxiv preprint doi: https://doi.org/10.1101/2021.11.04.21265894; this version posted December 17, 2021. The copyright holder for this preprint (which was not certified by peer review) is the author/funder, who has granted medRxiv a license to display the preprint in perpetuity. All rights reserved. No reuse allowed without permission.

A higher number of modules was associated with better performance in a few performancebased and patient-reported functional measures before and 6-months after surgery but with poorer

381 performance in a few functional measures 24-months after surgery (Figs. 3 \& 4). Before surgery,

382 participants with 3 modules demonstrated better scores on average than those with 2 modules in

383 all measures, and this difference was clinically meaningful in all measures except the 6MW

384 distance (Table 2). These results were statistically significant for the TUG $(p=0.002)$ and KOOS-

385 Pain $(p=0.005)$ scores and approached significance for the SCT $(p=0.060)$, KOOS-ADL $(p=$ 386 0.057), and KOOS-QOL $(p=0.065)$ scores. By 6-months after surgery, participants with 3

387 modules demonstrated better scores on average than those with 2 modules in all measures except 388 the KOOS-QOL subscale (Table 2). These differences were clinically meaningful for only the 389 SCT, which also approached statistical significance $(p=0.052)$ and were statistically significant 390 but not clinically meaningful for the TUG test $(p=0.028)$. By 24-months after surgery, participants 391 with 2 modules had better scores on average than those with 3 modules in SCT, 6MW, KOOS392 Symptoms scores (Table 2). These differences were clinically meaningful for the SCT and for the $3936 \mathrm{MW}$, which was also statistically significant $(p=0.006)$. 

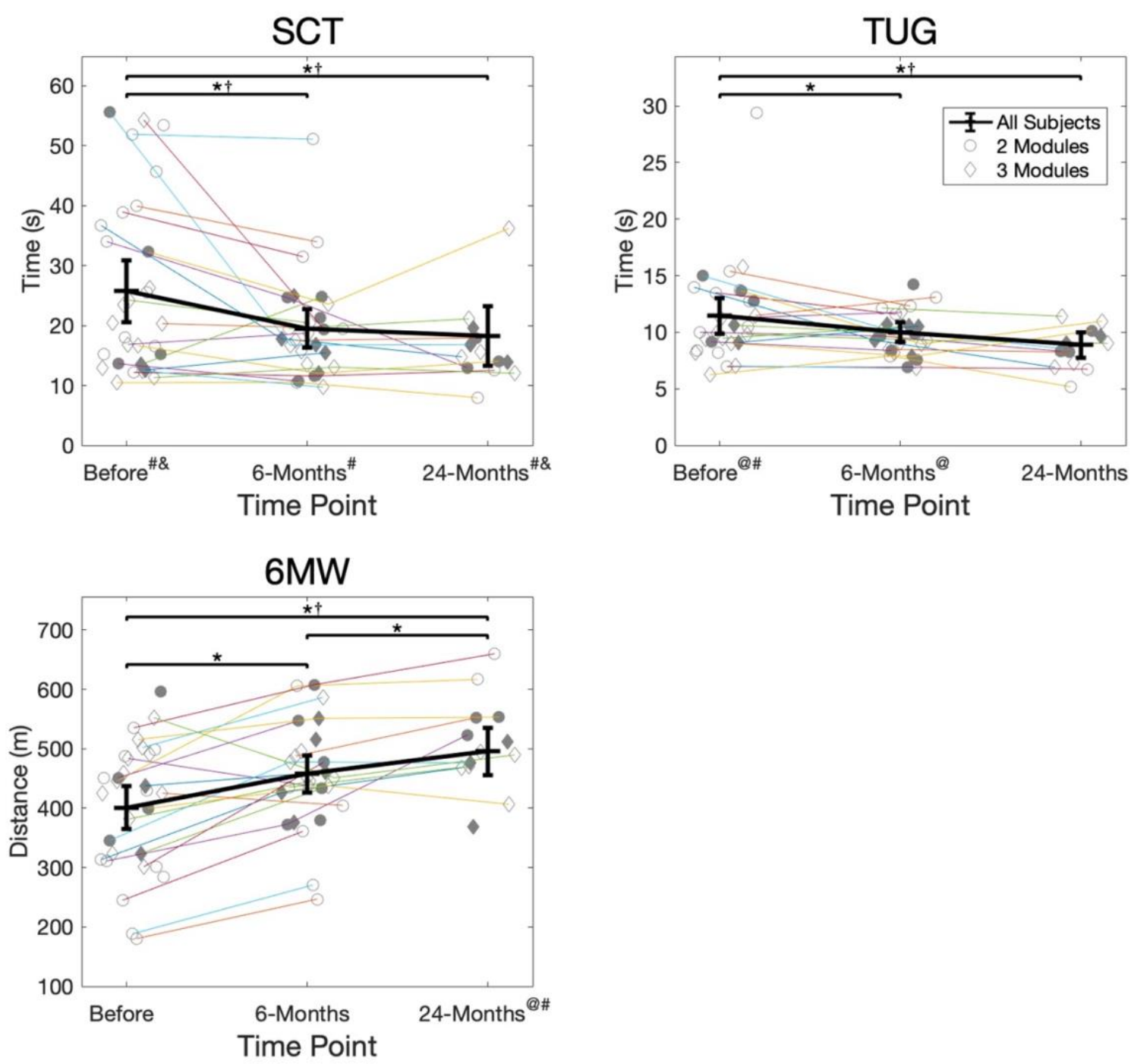

Fig. 3: Performance-Based Function. Performance-based functional scores (SCT, TUG, 6MW) for each participant at each time point. Participants who were present for consecutive testing time points are connected. Filled symbols indicate participants with proper module organization. Thick black lines indicate the group estimated means and $95 \%$ confidence intervals at each time point, determined by the GLMM. $* / \uparrow=$ statistically significant $(*)$ and clinically meaningful $(\dagger)$ differences in function between time points. @/\# = statistically significant (@) and clinically meaningful (\#) differences in function between groups demonstrating the same number of modules at each time point. $\&=$ clinically meaningful differences in function between groups demonstrating proper or poor module organization at each time point. There were no statistically significant differences. 

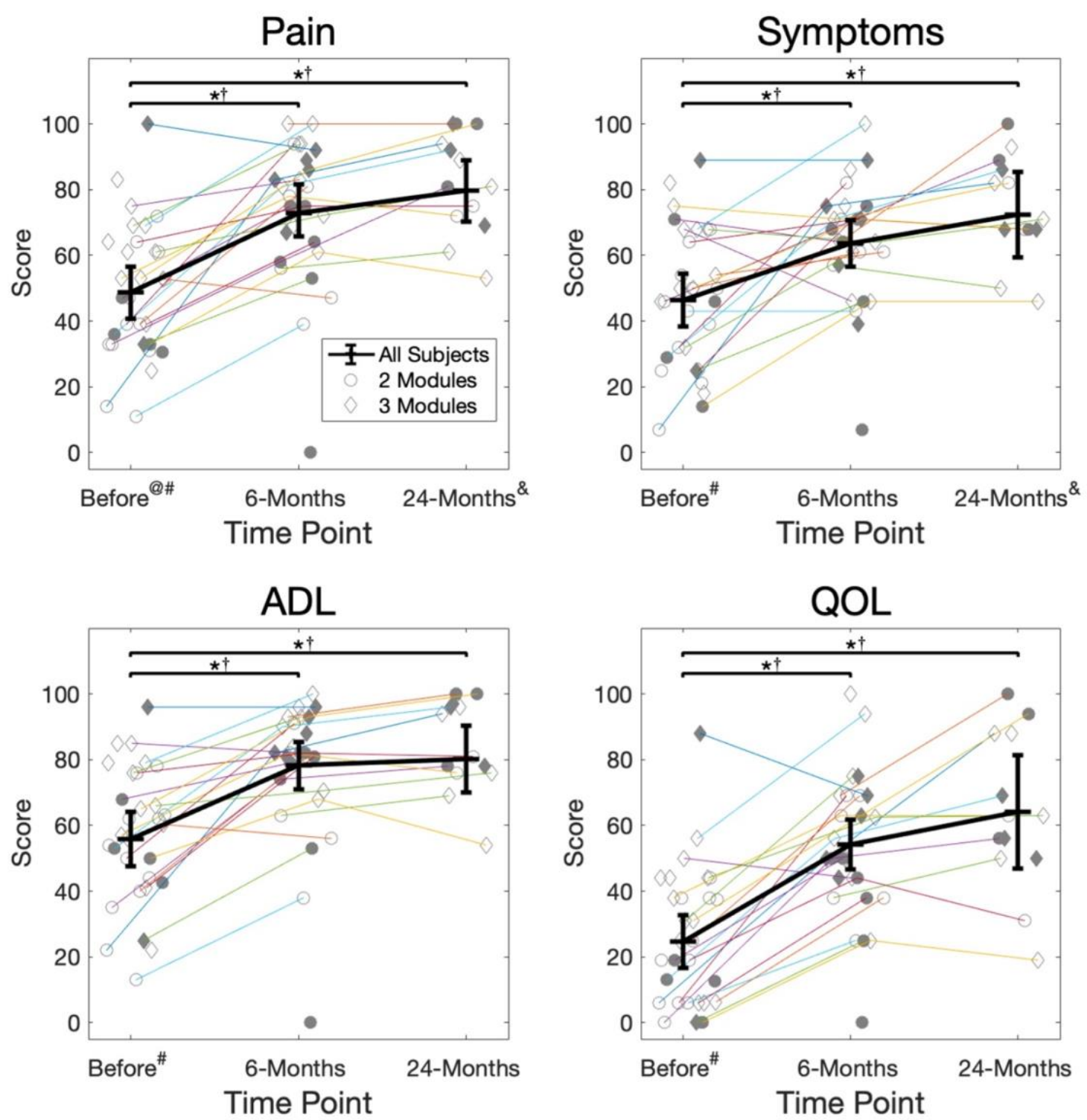

408

Fig. 4: Patient-Reported Function. KOOS survey subscale scores (Pain, Symptoms, ADL, QOL) for each participant at each time point. Participants who were present for consecutive testing time points are connected. Filled symbols indicate participants with proper module organization. Thick black lines indicate the group estimated means and $95 \%$ confidence intervals at each time point, determined by the GLMM.

$* / \uparrow=$ statistically significant $(*)$ and clinically meaningful $(\dagger)$ differences in function between time points.

@/\# = statistically significant (@) and clinically meaningful (\#) differences in function between groups demonstrating the same number of modules at each time point.

$\&=$ clinically meaningful differences in function between groups demonstrating proper or poor module organization at each time point. There were no statistically significant differences. 
medRxiv preprint doi: https://doi.org/10.1101/2021.11.04.21265894; this version posted December 17, 2021. The copyright holder for this preprint (which was not certified by peer review) is the author/funder, who has granted medRxiv a license to display the preprint in perpetuity.

All rights reserved. No reuse allowed without permission.

424 Table 2: Functional Measures within Module Number Groups.

\begin{tabular}{|c|c|c|c|c|c|c|}
\hline & & Two Modules & Three Modules & $p$ & Estimate & $95 \% \mathrm{CI}$ \\
\hline \multirow{3}{*}{$\begin{array}{c}\text { Number of } \\
\text { Subjects }\end{array}$} & Pre-TKA & $\mathrm{n}=16$ & $\mathrm{n}=14$ & - & - & - \\
\hline & 6-months Post-TKA & $\mathrm{n}=12$ & $\mathrm{n}=14$ & - & - & - \\
\hline & 24-months Post-TKA & $\mathrm{n}=5$ & $\mathrm{n}=8$ & - & - & - \\
\hline \multirow{3}{*}{$\operatorname{SCT}(s)$} & Pre-TKA & $30.2 \pm 15.3$ & $21.0 \pm 11.2$ & $0.060^{\dagger}$ & 9.2 & {$[-0.42,18.90]$} \\
\hline & 6-months Post-TKA & $22.5 \pm 11.5$ & $16.4 \pm 4.2$ & $0.052^{\dagger}$ & 6.1 & {$[-0.05,12.19]$} \\
\hline & 24-months Post-TKA & $16.1 \pm 3.6$ & $19.5 \pm 7.6$ & $0.434^{\dagger}$ & -3.4 & {$[-12.44,5.70]$} \\
\hline \multirow{3}{*}{ TUG (s) } & Pre-TKA & $13.1 \pm 5.3$ & $9.6 \pm 2.3$ & $\mathbf{0 . 0 0 2}^{\dagger}$ & 3.5 & {$[1.63,5.35]$} \\
\hline & 6-months Post-TKA & $10.8 \pm 2.5$ & $9.4 \pm 1.4$ & 0.028 & 1.4 & {$[0.17,2.60]$} \\
\hline & 24-months Post-TKA & $9.2 \pm 1.9$ & $8.9 \pm 1.6$ & 0.803 & 0.3 & {$[-2.51,3.16]$} \\
\hline \multirow{3}{*}{$6 \mathrm{MW}(\mathrm{m})$} & Pre-TKA & $379.7 \pm 123.8$ & $425.9 \pm 76.8$ & 0.128 & -46.7 & {$[-107.79,14.49]$} \\
\hline & 6-months Post-TKA & $453.8 \pm 116.3$ & $467.9 \pm 53.7$ & 0.621 & -13.1 & {$[-67.74,41.44]$} \\
\hline & 24-months Post-TKA & $546.1 \pm 55.7$ & $468.4 \pm 48.4$ & $0.006^{\dagger}$ & 78.5 & {$[29.27,127.72]$} \\
\hline \multirow{3}{*}{$\begin{array}{l}\text { KOOS-Pain } \\
\text { (points) }\end{array}$} & Pre-TKA & $39.2 \pm 16.6$ & $58.8 \pm 19.8$ & $0.005^{\dagger}$ & -19.6 & {$[-32.58,-6.57]$} \\
\hline & 6-months Post-TKA & $69.8 \pm 24.6$ & $78.3 \pm 12.4$ & 0.186 & -8.6 & {$[-21.82,4.67]$} \\
\hline & 24-months Post-TKA & $80.6 \pm 13.5$ & $80.7 \pm 17.0$ & 0.987 & -0.1 & {$[-19.98,19.68]$} \\
\hline \multirow{3}{*}{$\begin{array}{l}\text { KOOS-Symptom } \\
\text { (points) }\end{array}$} & Pre-TKA & $40.3 \pm 18.8$ & $52.4 \pm 22.5$ & $0.152^{\dagger}$ & -12.1 & {$[-28.94,4.72]$} \\
\hline & 6-months Post-TKA & $60.5 \pm 19.8$ & $67.1 \pm 17.3$ & 0.393 & -6.6 & {$[-22.92,9.71]$} \\
\hline & 24-months Post-TKA & $79.0 \pm 13.8$ & $69.2 \pm 16.5$ & 0.418 & 9.7 & {$[-15.79,35.26]$} \\
\hline \multirow{3}{*}{$\begin{array}{l}\text { KOOS-ADL } \\
\text { (points) }\end{array}$} & Pre-TKA & $49.1 \pm 17.9$ & $63.0 \pm 22.3$ & $0.057^{\dagger}$ & -13.9 & {$[-28.17,0.46]$} \\
\hline & 6-months Post-TKA & $76.4 \pm 25.6$ & $80.0 \pm 9.5$ & 0.482 & -3.6 & {$[-15.35,8.08]$} \\
\hline & 24-months Post-TKA & $77.8 \pm 12.0$ & $83.2 \pm 15.9$ & 0.520 & -5.4 & {$[-23.85,12.98]$} \\
\hline \multirow{3}{*}{$\begin{array}{l}\text { KOOS-QOL } \\
\text { (points) }\end{array}$} & Pre-TKA & $17.7 \pm 15.0$ & $32.3 \pm 24.1$ & $0.065^{\dagger}$ & -14.7 & {$[-30.49,1.16]$} \\
\hline & 6-months Post-TKA & $57.2 \pm 20.0$ & $53.1 \pm 20.1$ & 0.515 & 4.1 & {$[-9.36,17.55]$} \\
\hline & 24-months Post-TKA & $61.7 \pm 28.4$ & $64.8 \pm 22.5$ & 0.832 & -3.1 & {$[-34.98,28.69]$} \\
\hline
\end{tabular}

425

426

427

428

429

430

431

432

433

434

435

436

Average functional measures within groups of participants demonstrating the same number of modules at each timepoint (estimated mean \pm 1 standard deviation). ${ }^{\dagger}$ indicates a clinically meaningful difference in function between the Two Modules and Three Modules groups. Hypothesis II: Function and Module Organization

Better module organization was not statistically associated with better performance-based function (SCT, TUG, or 6MW) or patient-reported function (KOOS subscales) before or after surgery (Figs. $3 \& 4$ ). However, the largest differences in function between the proper and poor organization groups occurred 24-months after surgery, with the proper organization group demonstrating better function on average in all performance-based and patient-reported measures (Table 3). These results approached statistical significance for the KOOS-Pain subscale $(p=0.061)$ and were clinically meaningful for the SCT, KOOS-Pain, and KOOS-Symptoms scores. 
medRxiv preprint doi: https://doi.org/10.1101/2021.11.04.21265894; this version posted December 17, 2021. The copyright holder for this preprint (which was not certified by peer review) is the author/funder, who has granted medRxiv a license to display the preprint in perpetuity.

Table 3: Functional Measures within Module Organization Groups.

439

\begin{tabular}{|c|c|c|c|c|c|c|}
\hline & & Poor & Proper & p-Value & Estimate & $95 \% \mathrm{CI}$ \\
\hline \multirow{3}{*}{$\begin{array}{c}\text { Number of } \\
\text { Subjects }\end{array}$} & Pre-TKA & $\mathrm{n}=24$ & $\mathrm{n}=6$ & - & - & - \\
\hline & 6-months Post-TKA & $\mathrm{n}=15$ & $\mathrm{n}=11$ & - & - & - \\
\hline & 24-months Post-TKA & $\mathrm{n}=7$ & $\mathrm{n}=6$ & - & - & - \\
\hline \multirow{3}{*}{$\mathrm{SCT}(\mathrm{s})$} & Pre-TKA & $26.1 \pm 14.2$ & $24.2 \pm 17.3$ & $0.750^{\dagger}$ & 2.0 & {$[-10.64,14.60]$} \\
\hline & 6-months Post-TKA & $19.9 \pm 10.7$ & $19.1 \pm 5.4$ & 0.824 & 0.7 & {$[-6.39,7.88]$} \\
\hline & 24-months Post-TKA & $19.6 \pm 9.3$ & $16.2 \pm 2.6$ & $0.487^{\dagger}$ & 3.4 & {$[-7.06,13.93]$} \\
\hline \multirow{3}{*}{ TUG (s) } & Pre-TKA & $11.3 \pm 4.8$ & $12.0 \pm 2.5$ & 0.695 & -0.6 & {$[-4.04,2.78]$} \\
\hline & 6-months Post-TKA & $10.2 \pm 1.9$ & $9.8 \pm 2.0$ & 0.679 & 0.3 & {$[-1.25,1.88]$} \\
\hline & 24-months Post-TKA & $8.5 \pm 2.3$ & $9.2 \pm 0.8$ & 0.540 & -0.7 & {$[-3.11,1.72]$} \\
\hline \multirow{3}{*}{ 6MW (m) } & Pre-TKA & $401.6 \pm 110.3$ & $399.9 \pm 97.4$ & 0.963 & 1.7 & {$[-75.03,78.46]$} \\
\hline & 6-months Post-TKA & $454.4 \pm 96.2$ & $462.2 \pm 79.6$ & 0.762 & -7.7 & {$[-60.33,44.85]$} \\
\hline & 24-months Post-TKA & $489.3 \pm 89.8$ & $502.0 \pm 69.3$ & 0.727 & -12.7 & {$[-92.51,67.11]$} \\
\hline \multirow{3}{*}{$\begin{array}{l}\text { KOOS-Pain } \\
\text { (points) }\end{array}$} & Pre-TKA & $49.5 \pm 19.2$ & $46.4 \pm 26.8$ & 0.729 & 3.2 & {$[-15.41,21.74]$} \\
\hline & 6-months Post-TKA & $77.3 \pm 19.1$ & $68.1 \pm 25.7$ & 0.116 & 9.2 & {$[-2.75,21.19]$} \\
\hline & 24-months Post-TKA & $75.2 \pm 14.6$ & $86.1 \pm 12.8$ & $0.061^{\dagger}$ & -11.0 & {$[-22.53,0.60]$} \\
\hline \multirow{3}{*}{$\begin{array}{c}\text { KOOS-Symptom } \\
\text { (points) }\end{array}$} & Pre-TKA & $46.8 \pm 19.6$ & $45.7 \pm 29.1$ & 0.920 & 1.1 & {$[-20.41,22.54]$} \\
\hline & 6-months Post-TKA & $63.4 \pm 15.7$ & $63.4 \pm 22.5$ & 0.999 & 0.0 & {$[-18.11,18.09]$} \\
\hline & 24-months Post-TKA & $67.3 \pm 17.3$ & $79.1 \pm 13.8$ & $0.315^{\dagger}$ & -11.8 & {$[-36.93,13.40]$} \\
\hline \multirow{3}{*}{$\begin{array}{l}\text { KOOS-ADL } \\
\text { (points) }\end{array}$} & Pre-TKA & $56.1 \pm 20.4$ & $55.9 \pm 24.2$ & 0.984 & 0.2 & {$[-18.51,18.88]$} \\
\hline & 6-months Post-TKA & $79.2 \pm 17.1$ & $76.6 \pm 26.8$ & 0.641 & 2.6 & {$[-10.72,15.97]$} \\
\hline & 24-months Post-TKA & $78.7 \pm 14.5$ & $83.9 \pm 10.6$ & 0.478 & -5.2 & {$[-21.13,10.70]$} \\
\hline \multirow{3}{*}{$\begin{array}{l}\text { KOOS-QOL } \\
\text { (points) }\end{array}$} & Pre-TKA & $24.4 \pm 17.7$ & $27.5 \pm 33.2$ & 0.756 & -3.0 & {$[-23.10,17.01]$} \\
\hline & 6-months Post-TKA & $56.8 \pm 22.4$ & $50.5 \pm 20.8$ & 0.355 & 6.3 & {$[-9.43,21.97]$} \\
\hline & 24-months Post-TKA & $63.2 \pm 26.3$ & $67.7 \pm 21.3$ & 0.759 & -4.5 & {$[-36.12,27.19]$} \\
\hline
\end{tabular}

Average functional measures within groups of participants with modules that were (Proper) or were not (Poor) organized like healthy controls at each timepoint (estimated mean \pm 1 standard deviation). ${ }^{\dagger}$ indicates a clinically meaningful difference in function between the Proper and Poor organization groups.

\section{Secondary Analysis: Changes in Modules}

While there were no significant differences in modules between participants grouped by time point, we observed changes in module number and organization in individual participants throughout the time course of recovery (Table 4). From before to 6-months after surgery, 63.2\% of participants present at both time points (12/19) demonstrated changes in module number and/or 
medRxiv preprint doi: https://doi.org/10.1101/2021.11.04.21265894; this version posted December 17, 2021. The copyright holder for this preprint (which was not certified by peer review) is the author/funder, who has granted medRxiv a license to display the preprint in perpetuity. All rights reserved. No reuse allowed without permission.

451 organization. From 6- to 24 -months after surgery, $80.0 \%$ of participants present at both time points

452 (8/10) demonstrated changes in module number and/or organization. From before to 24-months

453 after surgery, $100 \%$ of participants present at both time points (10/10) demonstrated changes in

454 module number and/or the organization of at least 1 module (Table 4).

Table 4: Count of Participants with Changes in Modules.

\begin{tabular}{c|cccc}
\hline \multicolumn{1}{c}{} & & $\begin{array}{c}\text { Pre-TKA to } \\
\text { 6-m Post-TKA } \\
\mathrm{n}=19\end{array}$ & $\begin{array}{c}\text { 6-m to 24-m } \\
\text { Post-TKA } \\
\mathrm{n}=10\end{array}$ & $\begin{array}{c}\text { Pre-TKA to } \\
\text { 24-m Post-TKA } \\
\mathrm{n}=10\end{array}$ \\
\hline \multirow{2}{*}{$\begin{array}{c}\text { Number of } \\
\text { Modules }\end{array}$} & Increase & $3(15.8 \%)$ & $1(10.0 \%)$ & $4(40.0 \%)$ \\
& No Change & $12(63.2 \%)$ & $7(70.0 \%)$ & $4(40.0 \%)$ \\
\cline { 2 - 5 } $\begin{array}{c}\text { Proper vs. Poor } \\
\text { Organization }\end{array}$ & Decrease & $4(21.1 \%)$ & $2(20.0 \%)$ & $2(20.0 \%)$ \\
\hline \hline Any Module & No Change & $12(63.2 \%)$ & $6(60.0 \%)$ & $5(50.0 \%)$ \\
Characteristic & Worsened & $2(10.5 \%)$ & $2(20.0 \%)$ & $1(10.0 \%)$ \\
\hline
\end{tabular}

6-m Post-TKA Post-TKA 24-m Post-TKA

Number of participants (\%) that were present at multiple time points and demonstrated changes in module characteristics. Proper organization describes participants whose organization matched those of healthy controls for all modules. Poor organization describes participants with at least 1 module that was not organized like healthy controls. Participants who are listed as having a change in "Any Module Characteristic" had a change in the number of modules and/or the organization of at least 1 module compared to healthy controls.

\section{DISCUSSION}

467 deficits in individuals after TKA, the purpose of this study was to determine the relationship

468 between modular control strategy and function in individuals before and at two time points after

469 TKA. Our findings partially confirmed our first hypothesis that better function would be related to

470 a higher number of modules. We found that participants with better performance-based function

471 before and 6-months after surgery and better patient-reported function before surgery had a higher

472 number of modules. However, at 24-months after surgery, a higher number of modules were 
medRxiv preprint doi: https://doi.org/10.1101/2021.11.04.21265894; this version posted December 17, 2021. The copyright holder for this

473 related to worse 6MW performance, which contradicts our first hypothesis. Our findings did not

474 strongly confirm our second hypothesis that better function would be related to module

475 organization that more closely resembled that of healthy controls. However, by 24-months after

476 surgery, participants with proper module organization had better function on average than those

477 with poor organization in all performance-based and patient-reported measures, with some

478 differences being clinically meaningful. Considerable participant drop-out by the 24-month time

479 point may have prevented us from detecting statistically significant differences in function

480 between groups demonstrating proper and poor module organization. While we did not find

481 differences in population-averaged modular control between timepoints, we did observe changes

482 in both module number and organization in individuals and in population-mean complexity, as

483 measured by tVAF. While the differences in tVAF between testing time points were statistically

484 significant for the 6- and 7-module solutions, they were likely not clinically meaningful, though a

485 clinically meaningful difference in tVAF values has not been established in the literature. Larger

486 differences in tVAF between time points were observed for the 1- and 2-module solutions, which

487 may indicate that module complexity is malleable in this population. Together with our

488 observations on module organization, these results indicate that motor modules are plastic and

489 suggest that neural control strategy is influenced by surgical intervention and rehabilitation in this

490 population.

The association we observed between number of modules and function partially confirms

492 the findings of Ardestani et al. (21), who found that a higher number of modules was associated 493 with better patient-reported function 1-year following TKA. While we found that better function 494 was associated with a higher number of modules in individuals with KOA prior to TKA, we did 495 not find this association by 24-months after surgery. Several methodological differences exist 
medRxiv preprint doi: https://doi.org/10.1101/2021.11.04.21265894; this version posted December 17, 2021. The copyright holder for this preprint (which was not certified by peer review) is the author/funder, who has granted medRxiv a license to display the preprint in perpetuity. All rights reserved. No reuse allowed without permission.

between the current study and Ardestani et al. (21) which may explain the differences in results. Ardestani et al. (21) measured patient-reported function using the Knee Functional Survey (KFS) (40), which assesses general patient satisfaction and symptoms, ability to complete activities of daily living, and ability to participate in sports and exercise. The KFS may most closely relate to the KOOS-Symptoms, KOOS-ADL, and KOOS-QOL subscales, which were not statistically related to number of modules in the current study. However, our small sample sizes, particularly by 24-months after surgery, may have prevented us from detecting associations between patientreported function and number of modules after surgery. Additionally, the methods for module extraction used by Ardestani et al. (21), including a strict error criterion of $90 \%$ accuracy between the experimental and reconstructed EMG, resulted in a range of 2-5 modules, whereas we saw only 2-3 modules. We believe our approach for calculating modules using 500 bootstrapped samples (41) and a previously developed, conservative VAF criteria (24) is robust. Lastly, participants in

508 Ardestani et al. (21) received cruciate-retaining implants while participants in the current study received posterior-stabilizing implants. The comparison of our results with those of Ardestani et al. (21) may suggest that proprioceptive inputs, which are lost as a result of sacrificing the cruciate

511 ligaments, influence neuromuscular control strategy. However, the lack of consistency in 512 methodologies across studies warrants further investigation into the influence of retaining the 513 posterior cruciate ligament on post-surgical neuromuscular control. Further, while Ardestani et al. 514 (21) indicated an association between a higher number of modules and better patient-reported 515 function at 1-year following TKA, our results indicate that the relationship between number of modules and function changes over the time course of recovery. The observed relationship between a higher number of modules and better function in some 518 measures before TKA reversed in some measures by 24-months after TKA. The group with 2 
medRxiv preprint doi: https://doi.org/10.1101/2021.11.04.21265894; this version posted December 17, 2021. The copyright holder for this preprint (which was not certified by peer review) is the author/funder, who has granted medRxiv a license to display the preprint in perpetuity. All rights reserved. No reuse allowed without permission. multiple trials may provide further insight into functional performance in tasks like walking (22).

538 Furthermore, relationships between module organization and function have been observed in 539 populations with neurologic movement disorders. Brough et al. (42) found that individuals with

modules 24-months after surgery demonstrated 6MW distances that were on average better, statistically and clinically, than those with 3 modules. Further analysis revealed that there were 2 participants with 2 modules that had significantly higher 6MW distances than the other participants at this time point which drove this result. Both participants demonstrated module organization that was different from the healthy controls, with one module that was dominated by the quadriceps and hamstrings and one module that was dominated by the plantarflexors and hamstrings such that the hamstrings were constantly active throughout the gait cycle. These participants also demonstrated better-than-average SCT and TUG performance at 24-months but had unremarkable KOOS scores and demographics measures. When examining all participants at 24-months postTKA, we found that 3 of the 5 participants $(60.0 \%)$ with 2 modules had proper organization while only 3 of the 8 participants (37.5\%) with 3 modules had proper organization. These results indicate that module organization, rather than number, may be a factor which is related to function in the long-term post-operative time frame (24-months after TKA).

Though there were no statistically significant differences in function between the proper and poor organization groups at any time point, we observed trends toward better function in all functional measures, except TUG, for the group with proper module organization at 24-months after TKA. While the number of modules has frequently been used as a metric for motor control, recent studies suggest that module analysis which examines the composition of modules across post-stroke hemiparesis without an independent plantarflexors module demonstrated poorer locomotor function compared to patients and controls with an independent plantarflexors module. 
medRxiv preprint doi: https://doi.org/10.1101/2021.11.04.21265894; this version posted December 17, 2021. The copyright holder for this preprint (which was not certified by peer review) is the author/funder, who has granted medRxiv a license to display the preprint in perpetuity. All rights reserved. No reuse allowed without permission.

542 Hayes et al. (25) also observed altered module composition and slower walking speeds in 543 individuals with chronic incomplete spinal cord injury compared to able-bodied individuals. While 544 there was not a significant relationship in the current study between function and module 545 organization, as it relates to the organization of healthy individuals, the observed trends toward 546 better function in those with module organization similar to healthy controls, with several 547 measures presenting with clinically meaningful differences between groups, indicates that there 548 may be a relationship between module composition and function which should be explored further. Investigation of the number and organization of modules over time revealed that 550 neuromuscular control was plastic in individual participants, and this neuroplasticity may be 551 related to functional outcomes. Previously, Hubley-Kozey et al. (15) found that shifts in activation 552 patterns of some muscles from before surgery to 1-year after TKA were accompanied by 553 improvements in knee flexor and extensor strength and patient-reported outcomes (via WOMAC 554 Index (43)) but were still statistically different from the patterns of asymptomatic individuals. In 555 the present study, we observed statistically significant and clinically meaningful improvements in 556 all functional measures from before to after surgery which accompanied population-mean 557 decreases in several tVAF measures. While small sample sizes ( $<10$ present at all time points) 558 prevented us from using statistical analysis to assess the association between changes in function 559 and changes in module characteristics between time points, these results suggest that there may be 560 an underlying relationship between improvements in function and increased module complexity.

561 Further, when comparing function at 6- to 24-months, there was a larger improvement in all 562 functional measures for groups with proper organization than those with poor organization, with 563 the exception of TUG (Table 3). This observation may indicate that individuals with proper module 564 organization may have a greater capacity to improve function than those with poor organization. 
medRxiv preprint doi: https://doi.org/10.1101/2021.11.04.21265894; this version posted December 17, 2021. The copyright holder for this preprint (which was not certified by peer review) is the author/funder, who has granted medRxiv a license to display the preprint in perpetuity. All rights reserved. No reuse allowed without permission.

565 Though we were not able to characterize it in the present study, we believe these observations 566 suggest that there is a relationship between changes in function and changes in modular control 567 which should be investigated in future studies.

568 Our evidence that the neuromuscular control strategies adopted before surgery are not 569 permanent suggests that surgical intervention and rehabilitation have an influence on modular 570 control strategy. These results contrast Shuman et al. (44) who found no change in the distribution 571 of muscle weightings within modules after treatment in children with cerebral palsy. However, 572 while the present study focuses on an orthopaedic condition rather than a neurological disorder, 573 our results support the concepts presented by Ting et al. (26), who suggested that neuromuscular 574 control patterns can be influenced by rehabilitation in individuals with spinal cord injury, stroke, 575 and Parkinson's disease. Our results also support the findings of Roelker et al. (38) who found 576 differences in motor modules between individuals with KOA and healthy, age-matched controls, 577 indicating that the onset of KOA may alter neuromuscular control strategy. It remains unclear 578 whether the changes in neural control observed in the present study resulted from changes in 579 neuroanatomical structures (i.e. muscles, motor units, or even spinal/supraspinal structures) or are 580 products of the neuromechanical interactions (26) caused by changes in the mechanical 581 environment of the knee during surgery. While we did not collect detailed data on the rehabilitation 582 plans of the participants in the present pilot study, our results suggest that changes in 583 neuromuscular control strategies, explored through motor modules, occur throughout the treatment 584 and rehabilitation of an orthopaedic condition. The plasticity of control in this population and the association between modular control 586 and patient function at individual time points may provide a basis for modifying rehabilitation 587 programs to improve functional outcomes after TKA. The association between better function and 
medRxiv preprint doi: https://doi.org/10.1101/2021.11.04.21265894; this version posted December 17, 2021. The copyright holder for this preprint (which was not certified by peer review) is the author/funder, who has granted medRxiv a license to display the preprint in perpetuity. All rights reserved. No reuse allowed without permission.

588 a higher number of modules before and 6-months after surgery and trends toward better average 589 function in those with proper organization 24-months after surgery suggests that the relationships

590 between function and module number or organization may be uncoupled. Our results before and 591 6-months after TKA support the findings of others, who have suggested that higher modular 592 complexity indicates a higher number of independent motor strategies that can be used to complete 593 a task $(21,45)$, thus improving adaptability and function. Our work suggests that improvements in 594 function in TKA patients may initially present as increases in the number of modules recruited 595 during gait and that once individuals are capable of producing complex and discrete neuromuscular 596 control patterns, further functional improvements may present as improvements in module 597 organization. Further investigation is needed to determine the cause of the observed changes in 598 modular control. The findings of this future work will help to determine if such motor control 599 changes may be driven through rehabilitation programs in order to improve patient function.

600 This pilot study was based on a secondary analysis of EMG data collected in a separate 601 study, and as such, small sample sizes may have prevented us from observing greater associations 602 between modular control characteristics and function. The high BMI values, which are 603 representative of the general TKA population, resulted in increased motion artifact during EMG 604 collection and also limited the number of available trials for analysis. Further investigation is 605 necessary to further characterize the relationship between changes in modular control 606 characteristics and changes in function at the population level. A larger study may provide the 607 statistical power needed to detect potential associations between modular complexity and 608 functional outcomes. 
medRxiv preprint doi: https://doi.org/10.1101/2021.11.04.21265894; this version posted December 17, 2021. The copyright holder for this preprint (which was not certified by peer review) is the author/funder, who has granted medRxiv a license to display the preprint in perpetuity. All rights reserved. No reuse allowed without permission.

\section{CONCLUSIONS}

Some performance-based and patient-reported functional measures were related to

613 modular complexity and organization. The number and organization of modules in individuals

614 changed between the three testing time points in our study. We believe this new approach to

615 evaluating motor control in individuals with TKA provides valuable insight into the plasticity of

616 neural control strategies in patients and may help inform rehabilitation programs for patients

617 demonstrating unsatisfactory outcomes. Future work will build on the findings of this pilot study

618 and explore the influence of rehabilitation techniques, which target re-training neuromuscular

619 control, on functional outcomes.

620

\section{ACKNOWLEDGEMENTS}

622 The authors thank Dr. Jacqueline M. Lewis, Dr. Gregory M. Freisinger, Dr. Elena J. Caruthers,

623 Rachel K. Hall, and Elizabeth M. Leszcz for their contributions to data collection and processing.

624 We also thank Drs. Jeffrey F. Granger, Andrew H. Glassman, and Matthew D. Beal, who

625 performed the surgeries in this study, and Drs. Jason Payne and Alan Rogers, who performed the

626 radiographic grading of OA severity.

\section{GRANTS}

629 This research was supported by the National Science Foundation Graduate Research Fellowship 630 Program under Grant Nos. DGE-1343012 (SAR) and DGE-0822215 (EJC), a fellowship from The

631 Ohio State University (RRK), and by Grant Number R01AR056700 from the National Institute of

632 Arthritis and Musculoskeletal and Skin Diseases. The content is solely the responsibility of the 
medRxiv preprint doi: https://doi.org/10.1101/2021.11.04.21265894; this version posted December 17, 2021. The copyright holder for this preprint (which was not certified by peer review) is the author/funder, who has granted medRxiv a license to display the preprint in perpetuity. All rights reserved. No reuse allowed without permission.

authors and does not necessarily represent the official views of the National Institute of Arthritis and Musculoskeletal and Skin Diseases nor the National Institutes of Health.

\section{CONFLICT OF INTEREST STATEMENT}

None of the authors have conflicts of interest regarding the contents of this manuscript.

\section{REFERENCES}

1. Sloan M, Premkumar A, Sheth NP. Projected Volume of Primary Total Joint Arthroplasty in the U.S., 2014 to 2030. J Bone Joint Surg Am. 2018;100(17):1455-60.

2. Singh JA, O'Byrne M, Harmsen S, Lewallen D. Predictors of moderate-severe functional limitation after primary Total Knee Arthroplasty (TKA): 4701 TKAs at 2-years and 2935 TKAs at 5-years. Osteoarthritis and cartilage. 2010;18(4):515-21.

3. Berman AT, Zarro VJ, Bosacco SJ, Israelite C. Quantitative gait analysis after unilateral or bilateral total knee replacement. J Bone Joint Surg Am. 1987;69(9):1340-5.

4. Benedetti MG, Catani F, Bilotta TW, Marcacci M, Mariani E, Giannini S. Muscle activation pattern and gait biomechanics after total knee replacement. Clinical biomechanics (Bristol, Avon). 2003;18(9):871-6.

5. Wilson SA, McCann PD, Gotlin RS, Ramakrishnan HK, Wootten ME, Insall JN. Comprehensive gait analysis in posterior-stabilized knee arthroplasty. J Arthroplasty. 1996;11(4):359-67.

6. Su FC, Lai KA, Hong WH. Rising from chair after total knee arthroplasty. Clin Biomech (Bristol, Avon). 1998;13(3):176-81.

7. Yercan HS, Ait Si Selmi T, Sugun TS, Neyret P. Tibiofemoral instability in primary total knee replacement: a review, Part 1: Basic principles and classification. The Knee. 2005;12(4):257-66.

8. Stulberg SD, Loan P, Sarin V. Computer-assisted navigation in total knee replacement: results of an initial experience in thirty-five patients. J Bone Joint Surg Am. 2002;84-A Suppl 2:90-8.

9. Jeffery RS, Morris RW, Denham RA. Coronal alignment after total knee replacement. The Journal of bone and joint surgery British volume. 1991;73(5):709-14.

10. Bade MJ, Kohrt WM, Stevens-Lapsley JE. Outcomes before and after total knee arthroplasty compared to healthy adults. The Journal of orthopaedic and sports physical therapy. 2010;40(9):559-67.

11. Zeni JA, Jr., Snyder-Mackler L. Early postoperative measures predict 1- and 2-year outcomes after unilateral total knee arthroplasty: importance of contralateral limb strength. Physical therapy. 2010;90(1):43-54.

12. Smith AJ, Lloyd DG, Wood DJ. Pre-surgery knee joint loading patterns during walking predict the presence and severity of anterior knee pain after total knee arthroplasty. Journal of 
medRxiv preprint doi: https://doi.org/10.1101/2021.11.04.21265894; this version posted December 17, 2021. The copyright holder for this preprint (which was not certified by peer review) is the author/funder, who has granted medRxiv a license to display the preprint in perpetuity.

671 orthopaedic research : official publication of the Orthopaedic Research Society. 2004;22(2):260-

6726.

673 13. Davidson BS, Judd DL, Thomas AC, Mizner RL, Eckhoff DG, Stevens-Lapsley JE.

674 Muscle activation and coactivation during five-time-sit-to-stand movement in patients

675 undergoing total knee arthroplasty. J Electromyogr Kinesiol. 2013;23(6):1485-93.

676 14. Marmon AR, Snyder-Mackler L. Activation deficits do not limit quadriceps strength

677 training gains in patients after total knee arthroplasty. Int J Sports Phys Ther. 2014;9(3):329-37.

678 15. Hubley-Kozey CL, Hatfield GL, Astephen Wilson JL, Dunbar MJ. Alterations in

679 neuromuscular patterns between pre and one-year post-total knee arthroplasty. Clin Biomech

680 (Bristol, Avon). 2010;25(10):995-1002.

681 16. Ting LH, McKay JL. Neuromechanics of muscle synergies for posture and movement.

682 Curr Opin Neurobiol. 2007;17(6):622-8.

683 17. Lee WA. Neuromotor synergies as a basis for coordinated intentional action. J Mot

684 Behav. 1984;16(2):135-70.

685 18. Mussa-Ivaldi FA, Giszter SF, Bizzi E. Linear combinations of primitives in vertebrate

686 motor control. Proc Natl Acad Sci U S A. 1994;91(16):7534-8.

687 19. Olree KS, Vaughan CL. Fundamental patterns of bilateral muscle activity in human

688 locomotion. Biol Cybern. 1995;73(5):409-14.

689 20. Ivanenko YP, Poppele RE, Lacquaniti F. Five basic muscle activation patterns account

690 for muscle activity during human locomotion. J Physiol. 2004;556(Pt 1):267-82.

691 21. Ardestani MM, Malloy P, Nam D, Rosenberg AG, Wimmer MA. TKA patients with

692 unsatisfying knee function show changes in neuromotor synergy pattern but not joint

693 biomechanics. Journal of electromyography and kinesiology : official journal of the International

694 Society of Electrophysiological Kinesiology. 2017;37:90-100.

695 22. Allen JL, McKay JL, Sawers A, Hackney ME, Ting LH. Increased neuromuscular

696 consistency in gait and balance after partnered, dance-based rehabilitation in Parkinson's disease.

697 J Neurophysiol. 2017;118(1):363-73.

698 23. Allen JL, Kesar TM, Ting LH. Motor module generalization across balance and walking

699 is impaired after stroke. J Neurophysiol. 2019;122(1):277-89.

700 24. Clark DJ, Ting LH, Zajac FE, Neptune RR, Kautz SA. Merging of healthy motor

701 modules predicts reduced locomotor performance and muscle coordination complexity post-

702 stroke. J Neurophysiol. 2010;103(2):844-57.

703 25. Hayes HB, Chvatal SA, French MA, Ting LH, Trumbower RD. Neuromuscular

704 constraints on muscle coordination during overground walking in persons with chronic

705 incomplete spinal cord injury. Clin Neurophysiol. 2014;125(10):2024-35.

706 26. Ting LH, Chiel HJ, Trumbower RD, Allen JL, McKay JL, Hackney ME, et al.

707 Neuromechanical principles underlying movement modularity and their implications for

708 rehabilitation. Neuron. 2015;86(1):38-54.

709 27. Freisinger GM, Hutter EE, Lewis J, Granger JF, Glassman AH, Beal MD, et al.

710 Relationships between varus-valgus laxity of the severely osteoarthritic knee and gait, instability,

711 clinical performance, and function. J Orthop Res. 2017;35(8):1644-52.

712 28. Chaudhari AMW, Schmitt LC, Freisinger GM, Lewis JM, Hutter EE, Pan X, et al.

713 Perceived Instability Is Associated With Strength and Pain, Not Frontal Knee Laxity, in Patients

714 With Advanced Knee Osteoarthritis. J Orthop Sports Phys Ther. 2019;49(7):513-7.

715 29. Kellgren JH, Lawrence JS. Radiological assessment of osteo-arthrosis. Ann Rheum Dis.

716 1957;16(4):494-502. 
medRxiv preprint doi: https://doi.org/10.1101/2021.11.04.21265894; this version posted December 17, 2021. The copyright holder for this preprint (which was not certified by peer review) is the author/funder, who has granted medRxiv a license to display the preprint in perpetuity. All rights reserved. No reuse allowed without permission.

30. Rejeski WJ, Ettinger WH, Jr., Schumaker S, James P, Burns R, Elam JT. Assessing performance-related disability in patients with knee osteoarthritis. Osteoarthritis Cartilage. 1995;3(3):157-67.

31. Dobson F, Hinman RS, Roos EM, Abbott JH, Stratford P, Davis AM, et al. OARSI recommended performance-based tests to assess physical function in people diagnosed with hip or knee osteoarthritis. Osteoarthritis Cartilage. 2013;21(8):1042-52.

32. Kennedy DM, Stratford PW, Wessel J, Gollish JD, Penney D. Assessing stability and change of four performance measures: a longitudinal study evaluating outcome following total hip and knee arthroplasty. BMC Musculoskelet Disord. 2005;6:3.

33. Roos EM, Lohmander LS. The Knee injury and Osteoarthritis Outcome Score (KOOS): from joint injury to osteoarthritis. Health Qual Life Outcomes. 2003;1:64.

34. Kieliba P, Tropea P, Pirondini E, Coscia M, Micera S, Artoni F. How are Muscle Synergies Affected by Electromyography Pre-Processing? IEEE Trans Neural Syst Rehabil Eng. 2018;26(4):882-93.

35. Santuz A, Ekizos A, Janshen L, Baltzopoulos V, Arampatzis A. On the Methodological Implications of Extracting Muscle Synergies from Human Locomotion. Int J Neural Syst. 2017;27(5):1750007.

36. Torres-Oviedo G, Ting LH. Muscle synergies characterizing human postural responses. J Neurophysiol. 2007;98(4):2144-56.

37. Lee DD, Seung HS. Learning the parts of objects by non-negative matrix factorization. Nature. 1999;401(6755):788-91.

38. Roelker SA, Koehn RR, Caruthers EJ, Schmitt LC, Chaudhari AMW, Siston RA. Effects of Age and Knee Osteoarthritis on the Modular Control of Walking: A Pilot Study. medRxiv. 2021:2020.05.22.20110536.

39. Almeida GJ, Schroeder CA, Gil AB, Fitzgerald GK, Piva SR. Interrater reliability and validity of the stair ascend/descend test in subjects with total knee arthroplasty. Arch Phys Med Rehabil. 2010;91(6):932-8.

40. Weiss JM, Noble PC, Conditt MA, Kohl HW, Roberts S, Cook KF, et al. What functional activities are important to patients with knee replacements? Clin Orthop Relat Res. 2002(404):172-88.

41. Sawers A, Allen JL, Ting LH. Long-term training modifies the modular structure and organization of walking balance control. J Neurophysiol. 2015;114(6):3359-73.

42. Brough LG, Kautz SA, Bowden MG, Gregory CM, Neptune RR. Merged plantarflexor muscle activity is predictive of poor walking performance in post-stroke hemiparetic subjects. $\mathbf{J}$ Biomech. 2019;82:361-7.

43. Bellamy N, Buchanan WW, Goldsmith CH, Campbell J, Stitt LW. Validation study of WOMAC: a health status instrument for measuring clinically important patient relevant outcomes to antirheumatic drug therapy in patients with osteoarthritis of the hip or knee. $\mathrm{J}$ Rheumatol. 1988;15(12):1833-40.

44. Shuman BR, Goudriaan M, Desloovere K, Schwartz MH, Steele KM. Muscle synergies demonstrate only minimal changes after treatment in cerebral palsy. J Neuroeng Rehabil. 2019;16(1):46.

45. Safavynia SA, Torres-Oviedo G, Ting LH. Muscle Synergies: Implications for Clinical Evaluation and Rehabilitation of Movement. Top Spinal Cord Inj Rehabil. 2011;17(1):16-24. 